\title{
Primary neuroendocrine carcinoma of the kidney
}

\author{
Jana Dvorackova ${ }^{a}$, Jirka Macaka, Petr Brzula ${ }^{a}$, Radoslava Tomanovaa ${ }^{a}$, Jiri Dokuliil
}

\begin{abstract}
Background. The objective of the study was to report a rare case of primary neuroendocrine carcinoma of the right kidney in a 36 year old male.

Methods. The patient was clinically assessed; CT and OctreoScan scintigraphy were performed and levels of 5-HIAA, vanillylmandelic acid and NSE were determined. The tumor and metastases were histologically and immunohistochemically examined.

Results. The imaging methods showed a cystic tumor in the lower pole of the right kidney. Macroscopically, the entire tumor was sized $8 \times 8 \times 7 \mathrm{~cm}$. Histologically, it was made up of ribbon-line or trabecular patterns of tumor cells. Occasional adenomatoid and cystic structures were present. The tumor cell nuclei were round or oval, with no irregularities and fine lumpy chromatin. The mitotic count was $<1 / 10 \mathrm{HPF}$ and the proliferation marker Ki- 67 was $<1 \%$ of tumor cells. Immunohistochemically, the tumor cells were positive with antibodies against chromogranin A, synaptophysin, CD56 (focally), cytokeratins AE1-AE3 (focally), vimentin (most cells), glucagon (focally), and pancreatic polypeptide (PP; focally). Antibodies against serotonin, somatostatin, gastrin, vasoactive intestinal polypeptide (VIP) and calcitonin did not react with the tumor. The results of biochemical markers (5-HIAA, vanillylmandelic acid and NSE) did not correlate with development or treatment of the tumor.

Conclusions. Primary neuroendocrine carcinoma of the kidney was diagnosed both histologically and immunohistochemically. The patient was clinically investigated using CT and OctreoScan scintigraphy. Within two years from nephrectomy, metastases were found in the right humerus and retrocaval lymph nodes. The metastatic lesions were surgically removed. Currently, the patient's condition is good, with no tumor progression detected.
\end{abstract}

Key words: kidney neoplasm, neuroendocrine tumor, carcinoid

Received: October 21, 2011; Accepted with revision: April 25, 2012; Available online: June 1, 2012 http://dx.doi.org/10.5507/bp.2012.053

${ }^{a}$ Department of Pathology, University Hospital and Faculty of Medicine University of Ostrava, Czech Republic ${ }^{b}$ Department of Oncology, University Hospital and Faculty of Medicine University of Ostrava Corresponding author: Jiri Macak, e-mail: macak.jirka@seznam.cz

\section{INTRODUCTION}

Primary neuroendocrine tumors of the kidney are rare. They occur in both the renal parenchyma and the renal pelvis $^{1-6}$. Individual tumors and series of five or six cases have been reported ${ }^{7,8}$. The largest series of 21 patients with renal carcinoids (well-differentiated neuroendocrine tumors) was investigated by Hansel et al. ${ }^{6}$. The patients were treated in five large US hospitals over a period of 36 years. So far, about 90 cases of the tumor have been described ${ }^{9}$. Most frequently, the tumor develops in the horseshoe kidney ${ }^{10,11}$. Hansel et al. ${ }^{6}$ found the horseshoe kidney in $19 \%$ of cases. Sporadically, synchronous well-differentiated neuroendocrine tumors and adenocarcinoma within the teratoma of the horseshoe kidney have been reported ${ }^{11}$.

\section{CASE REPORT}

A 36 year old male was admitted to the university hospital due to epigastric pain and dyspepsia three years previously. The 5-hydroxyindoleacetic acid (5-HIAA) test showed $41.0 \mu \mathrm{mol} / 24 \mathrm{hrs}$ (reference range, 10.4$47.1 \mu \mathrm{mol} / 24 \mathrm{hrs}$ ). The vanillylmandelic acid level was $31.2 \mu \mathrm{mol} / 24 \mathrm{hrs}$ (reference range, 0-33 $\mu \mathrm{mol} / 24 \mathrm{hrs}$ ).
During the hospital stay, the vanillylmandelic acid levels fluctuated between 17.9 and $53.2 \mu \mathrm{mol} / 24 \mathrm{hrs}$. Serum neuron-specific enolase (NSE) levels did not exceed $10.3 \mu \mathrm{g} / \mathrm{L}$ (reference cut-off, $12.5 \mu \mathrm{g} / \mathrm{L}$ ) throughout the hospitalization. Based on the clinical results, nephrectomy of the right kidney was performed.

Two months later, OctreoScan scintigraphy detected two lesions with increased somatostatin receptor density. One lesion was in the proximal third of the right humerus; the other was localized in the epigastrium but not specifically. The former lesion was assessed by CT angiography. Subsequent magnetic resonance imaging (MRI) confirmed a metastasis in the humerus but failed to show alterations in the epigastrium. One year later, a small increase in the right humerus lesion was revealed on X-ray. Subsequent biopsy examination confirmed metastatic neuroendocrine carcinoma. Two and half years after nephrectomy, resection of the humerus was performed. Postoperatively, PET/CT revealed a lesion in the retrocaval lymph nodes of the L1-L2 region. The nodes were surgically removed. Histological examination confirmed a neuroendocrine carcinoma metastasis. At present, the patient is free from tumor symptoms. His levels of the studied markers were of no value and no correlation with tumor development or treatment was found. 


\section{MATERIALS AND METHODS}

The kidney and lymph nodes were fixed in neutral formalin and the tumor tissue specimens were processed in the Autotechnicon. The paraffin-embedded sections were stained with hematoxylin and eosin.

Immunohistological evaluation was carried out using the avidin-biotin complex (ABC) method as usual, according to the manufacturer's instructions. The following antibodies were used (dilutions as shown in the brackets): AE1-AE3, clone AE1-AE3 (1:50), CK20, clone Ks 20.8 (prediluted), CK7, clone OU-TL 12/13 (1:50), NSE, clone $2 \mathrm{~F} 11^{1}(1: 50)$, rabbit anti-human gastrin polyclonal antibody (1:2000), vimentin, clone Vim 3B4 (1:100), rabbit anti-human somatostatin polyclonal antibody, (1:1000), mouse anti-human serotonin monoclonal antibody, clone 5HT-H209 (1:100), rabbit anti-human glucagon polyclonal antibody, clone A0565 (1:1000) - the antibodies were produced by Dako, Glostrup, Denmark; synaptophysin, clone 27G12 (1:100), chromogranin A, clone 5H7 (1:100), CD56, clone 1B6 (1:50) - antibodies manufactured by Novocastra, Newcastle-upon-Tyne, UK; rabbit anti-pancreatic polypeptide polyclonal antibody, clone 18-0043 (1:100) - Invitrogen, Lofer, Austria; VIP (vasoactive intestinal peptide) (1:500) - Immunostar, USA; rabbit anti-calcitonin polyclonal antibody, clone SP17 (1:20) - Thermo Scientific, Fremont, USA.

\section{RESULTS}

\section{Macroscopic findings}

In the renal hilum, a $5 \times 5 \times 6 \mathrm{~cm}$ cyst was found. The cavity was filled with dark red liquid. The inner surface of the cavity contained brownish soft areas of tissue. The cyst cavity was just adjacent to compact whitish tumor nodules affecting the renal medulla. The overall size of the lesion was $8 \times 8 \times 7 \mathrm{~cm}$ (Fig. 1). The cyst was in the close proximity to the renal pelvis.

\section{Histopathology}

The tumor itself was made up of ribbon-like or trabecular patterns of cylindrical cells. The nuclei were round or oval, localized mostly in the cell center. Occasional pseudoglandular and cystic structures were present (Fig. 2 ). At the basal area of the tumor cells, the plasma was of granular appearance. The tumor cells had a mitotic count of $<1$ mitosis/10HPF; the proliferation marker Ki-67 level was much lower than $1 \%$. Metastases in the lymph node and humerus were of a histologically similar appearance to that in the kidney. Also in these places, the mitotic count was 1/10HPF and the Ki-67 index was 1-2\%.

Immunohistologically, the tumor cells were positive with antibodies against chromogranin A (Fig. 3), synaptophysin (Fig. 4), CD56 (focally), vimentin (most cells), glucagon (focally), pancreatic polypeptide (PP) (focally), and cytokeratins AE1-AE3 (focally). The other markers were negative.

\section{DISCUSSION}

Well-differentiated neuroendocrine carcinoma is mostly observed in the gastrointestinal tract. Most frequently, it is localized in the small and large intestines and stomach. It is less frequent in the respiratory system. Sporadically, it is seen in parenchymal organs such as the liver and kidneys. In the liver parenchyma, it mostly arises from scattered neuroendocrine cells of bile duct or gall bladder mucosae. In the kidneys, the histogenetic origin of these tumors is unclear. The tumor quite often develops in the horseshoe kidney. In such cases, the clinical course is much more benign than in tumors occurring in normal kidneys ${ }^{12}$.

Primary neuroendocrine carcinoma of the kidney is most prevalent in patients around 50 years of age. It is clinically manifested by hematuria and unspecified pain in the lumbar region. Shurtleff et al. ${ }^{13}$ found that in approximately $20 \%$ (out of 43 cases), the course is asymptomatic. Gradually, the tumor enlarges and only then clinical symptoms may appear. In our case, it was $8 \mathrm{~cm}$. In more than $48 \%$ of cases, the tumor is cystic, such as in our patient. In the aforementioned series of 43 patients with primary neuroendocrine carcinoma of the kidney, metastases in the lymph nodes were found in approximately $18 \%$. Carcinoid syndrome was diagnosed in nearly $14 \%$ of cases. In the reported cases, tumor cells most frequently expressed PP, VIP and serotonin ${ }^{12}$. In our case, two years and six months after nephrectomy, lesions were found in the proximal humerus and lymph nodes paravertebrally in the subhepatic region. In both sites, metastases of well-differentiated neuroendocrine carcinoma were histologically confirmed. Expression of the proliferation marker Ki-67 was more prominent in these sites than in the primary tumor of the kidney.

The histogenetic origin of primary neuroendocrine carcinoma of the kidney is unclear. Neuroendocrine cells are not mentioned in histological descriptions of the normal parenchyma of the kidney, renal pelvis or ureter. Progenitor cells incorporated into the renal parenchyma during organogenesis are considered. Some authors ${ }^{14,15}$ found small nests of paraganglionic cells from which neuroendocrine tumors may arise. Nests of these cells were detected in the hilar region of the kidney.

Parada et al. ${ }^{16}$ reported chromophobe renal cell carcinoma with neuroendocrine differentiation, an entity described in the only case. According to the authors, both types of lesions have a common origin in renal tubular cells. Neuroendocrine differentiation was suggested by not only immunohistochemical assay but also neurosecretory granules found in tumor cell cytoplasm by electron microscopy. Rarely, neuroendocrine differentiation is observed in microcystic urothelial cell carcinoma of the renal pelvis ${ }^{17}$. Primary neuroendocrine carcinoma of the kidney may be mimicked by neuroendocrine cancer metastasis as reported in Merkel cell carcinoma metastatic to the kidney ${ }^{18}$.

Some authors think that the tumors arise from neuroendocrine cells occurring in the mucosa of the renal pelvis in intestinal metaplasia ${ }^{19,20}$. 


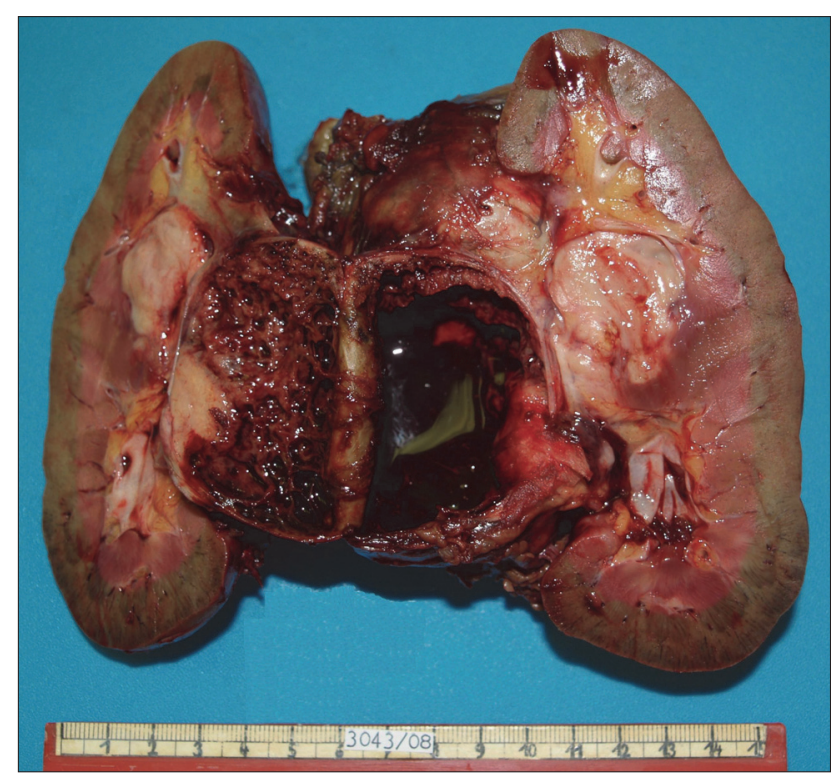

Fig. 1. Section of the kidney with cystic tumor.

The histological picture of the neuroendocrine carcinoma of the kidney was medium-sized tumor cells arranged into trabecules or ribbons. That is, structures similar to those observed in these tumors in the gastrointestinal tract. In our case, glandular structures were also seen that tended to form cyst cavities. One such cavity occupied a considerable part of the tumor. Less frequently, large cell neuroendocrine carcinoma is seen ${ }^{21,22}$. Some authors ${ }^{23,24}$ claim that neuroendocrine carcinoma of the renal pelvis is more frequently associated with transitional cell carcinoma, adenocarcinoma or squamous cell carcinoma than with the same tumors arising in the renal parenchyma.

At the molecular genetic level, abnormalities of chromosome 3 were detected ${ }^{1}$.

\section{ACKNOWLEDGEMENT}

Authors thank Dr. O. Koperek, Department of Pathology, AKH Vienna, for his help with immunohistochemical examinations.

\section{REFERENCES}

1. Kuroda N, Alvarado-Cabrero I, Sima R, Hes O, Michal M, Kinoshita H, Matduda T, Ohe CH, Sakaida N, Vemura Y, Lee GH. Renal carcinoid tumor: an immunohistochemical and molecular genetic study of four cases. Oncology letters 2010;1:87-90.

2. Kuroda N, Katto K, Tamura M, Hes O, Michal M, Hayashi Y, Lee GH. Carcinoid tumor of renal pelvis: consideration on the histogenesis. Pathol Int 2008;58:51-4.

3. Yoo J, Park S, Lee HJ, Kang SJ, Kim BK. Primary carcinoid tumor arising in a mature teratoma of the kidney a case report and review of the literature. Arch Pathol Lab Med 2002;126:979-1.

4. Romero FR, Rais-Bahrami S, Permpongkosol S, Fine SW, Kohanin $\mathrm{S}$, Jarrett TW. Primary carcinoid tumor of the kidney. J Urol 2006;176:2359-6.

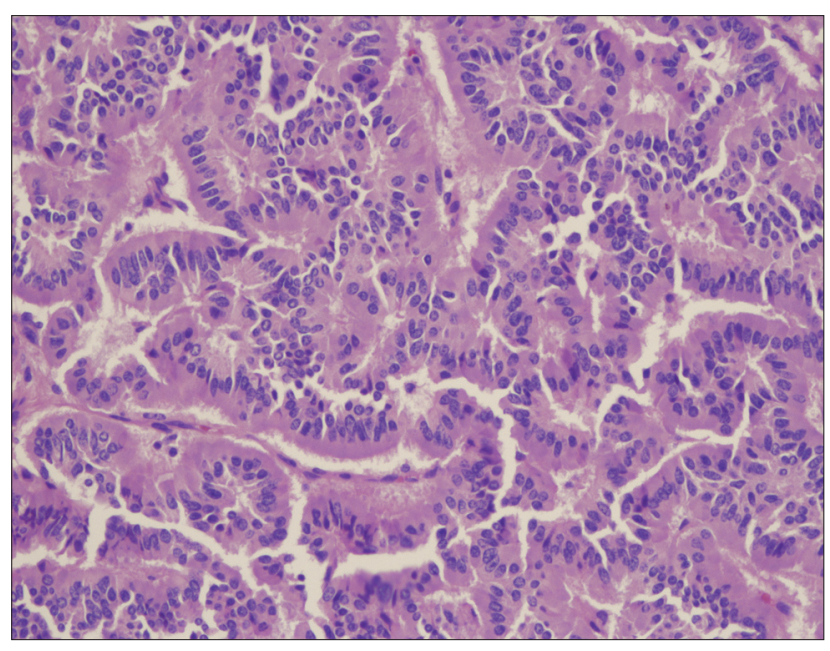

Fig. 2. Cylindrical cells of well-differentiated neuroendocrine carcinoma (HE, 400x).

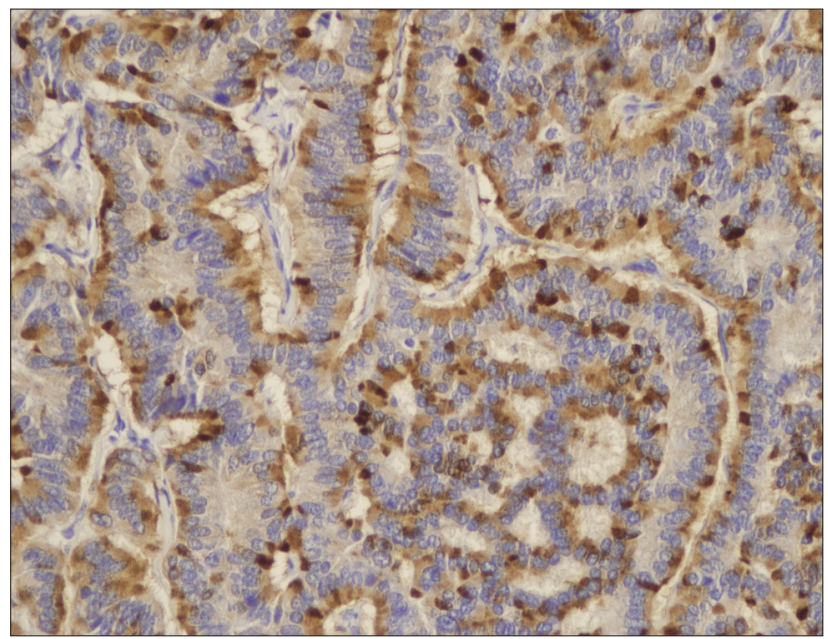

Fig. 3. Tumor cells mostly at the basal area react positively with an antibody against chromogranin (400x).

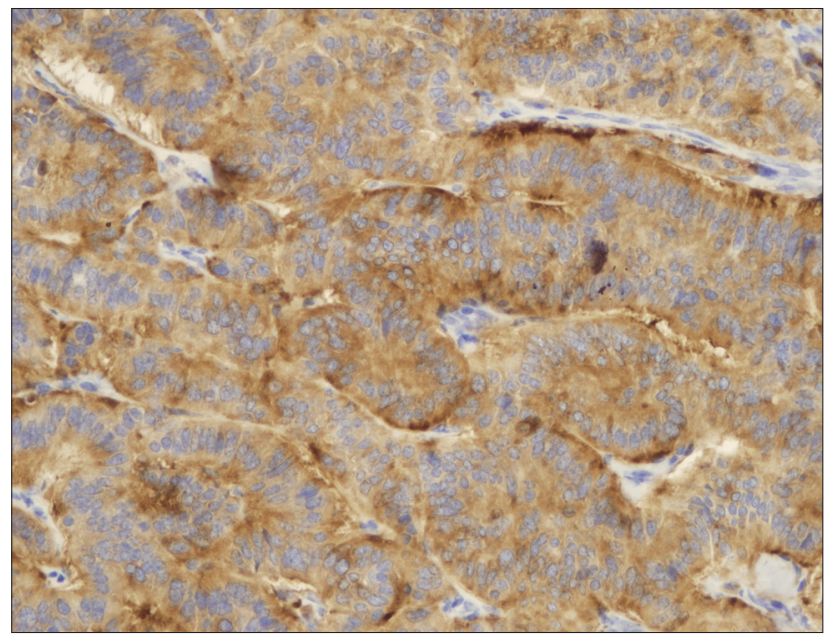

Fig. 4. Positive finding in tumor cells with an antibody against synaptophysin (200x). 
5. Murali R, Kneale K, Lalak N, Delprad W. Carcinoid tumors of the urinary tract and prostate. Arch Pathol Lab Med 2006;130:1693-6.

6. Hansel DE, Epstein Jl, Berbescu E, Fine S, Young R, Cheville J. Renal carcinoid tumor: a clinicopathologic study of 21 cases. Am J Surg Pathol 2007;31:1539-4.

7. Raslan WF, Ro JY, Ordonez NG, Amin MB, Troncoso P, Sella A, Ayala AG. Primary carcinoid of the kidney. Immunohistochemical and ultrastructural studies of five patients. Cancer 1993;72:2660-6.

8. Lane BR, Chery F, Jour G, Sercia L, Nagi-Galluzzi C, Novick AC, Zhou M. Renal neuroendocrine tumours: a clinicopathological study. BJU Int 2007;100:1030-5.

9. Jain D, Sharma CH, Singh K, Gupta NP. Primary carcinoid tumor of the kidney: case report and brief review of literature. Ind J Patho Microbiol 2010;53:772-4.

10. Isobe H, Takashima H, Higashi N, Murakami Y, Fujita K, Hanazawa K Fujime M, Matsumoto T. Primary carcinoid in a horseshoe kidney. Inter J Urol 2000;7:184-8.

11. Armah HB, Parwani AV, Perepletchikov AM. Synchronous primary carcinoid tumor and primary adenocarcinoma arising within mature cystic teratoma of horseshoe kidney: a unique case report and review of the literature. Diagn Pathol 2009;4:1-10.

12. Krishnan B, Truong LD, Saleh G, Sirbasku DM, Slawin KM. Horseshoe kidney is associated with an increased relative risk of primary renal carcinoid tumor. J Urol 1997;157:2059-6.

13. Shurtleff BT, Shvarts O, Rajfer. Carcinoid tumor of the kidney: case report and review of the literature. Rev Urol 2005;7:229-3.

14. Guy L, Bégin LR, Oligny LL, Brock GB, Chevlier S, Aprikian AG. Searching for an intrinsic neuroendocrine cell in the kidney. Pathol Res Pract 1999;195:25-30.
15. Kawabata K. Searching for an intrinsic neuroendocrine cell in the kidney. Letter to the editor. Pathol Res Pract 1999;195:865-6.

16. Parada DD, Pena KB. Chromophobe renal cell carcinoma with neuroendocrine differentiation. APMIS 2008;116:859-5.

17. Pacchioni D, Bosco M, Allia E, Mussa B, Mikuz G, Bussolati G. Microcystic urothelial cell carcinoma with neuroendocrine differentiation arising in renal pelvis. Report of a case. Virchows Arch 2009;454:223-7.

18. Pollheimer VS, Bodo K, Pollheimer MJ, Zigeuner R, Langer C. Merkel cell carcinoma metastasizing to the kidney mimicking primary neuroendocrine renal cancer. APMIS 2007;115:774-7.

19. Gordon A. Intestinal metaplasia of the urinary tract epithelium. $J$ Pathol Bacteriol 1963;85:441-5.

20. Shurtleff BT, Shvarts O, Rajfer J. Carcinoid tumor of the kidney: case report and review of the literature. Rev Urol 2005;7:229-3.

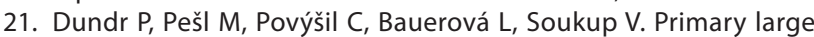
cell neuroendocrine carcinoma of the kidney. Pathol Oncol Res 2010;16:139-2.

22. Jiang SX, Mikami T, Umezawa A, Saegusa M, Kameya T, Okayasu I. Gastric large cell neuroendocrine carcinomas: a distinct clinicopathologic entity. Am J Surg Pathol 2006;30:945-3.

23. Mazzucchelli A, Morichetti D, Lopez-Beltran A, Cheng L, Scarpelli M, Kirkali Z, Montironi R. Neuroendocrine tumours of the urinary system and male genital organs: clinical significance. BJU Int 2009;103:1464-70.

24. Guillou L, Duvoisin B, Chobez C, Chapuis G, Costa J. Combined small-cell and transitional cell carcinoma of the renal pelvis. A light microscopic, immunohistochemical and ultrastructural study of a case with literature review. Arch Pathol Lab Med 1993;117:239-3. 